\title{
ANALISIS PERJANJIAN INTERNASIONAL DAN DAMPAK TERHADAP HUBUNGAN KERJASAMA INDONESIA-FIJI
}

\section{Heni Novalisa Tabisu, Aartje Tehupeiory, Diana R. W Napitupulu}

Universitas Kristen Indonesia (UKI) Jakarta, Indonesia

Email: henitabisu23@gmail.com, aartje.tehupeiory@uki.ac.id, notarisdn@gmail.com

\begin{tabular}{ll}
\hline INFO ARTIKEL & ABSTRAK \\
\hline Diterima & Indonesia Australia Ekonomi Partnership merupakan perjanjian \\
25 Oktober 2021 & kemitraan atau disebut dengan perjanjian bilateral kedua negara. \\
Direvisi & Perjanjian ekonomi ini akan mengatur pasar Indonesia untuk \\
Disetujui & Indonesia berdasarkan nilai akan dihitung bebas biaya bea. \\
15 November 2021 & Dalam perjanjian ini, penulis menemukan adanya peningkatan \\
Kata Kunci: & ekonomi Indonesia saat ikut dalam perjanjian Internasional I-A \\
analisis perjanjian; & CEPA Agreement. Peningkatan terjadi karena adanya \\
internasional; & minimalisir resiko kerugian bagi kedua negara dalam bidang \\
kerjasama & ekonomi. Metode yang digunakan dalam penelitian ini yaitu \\
indonesia-fiji & metode penelitian hukum normatif yaitu merupakan penelitian \\
& hukum kepustakan. Data yang digunakan merupakan data \\
& sekunder yang berasal dari buku-buku serta artikel tentang \\
& perjanjian dagang antara Indonesia dan Australia. Selain itu, \\
& pendekatan yang digunakan adalah pendekatan konsep serta \\
& pendekatan perundang-undangan. Kerangka teori yang dipakai \\
& sebagai dasar analisis adalah teori perjanjian internasional \\
& menurut Mochtar Kusumaatmadja yang menjelaskan tentang \\
& perjanjian internasional merupakan perjanjian yang diadakan \\
& antara bangsa-bangsa bertujuan untuk mengakitkan hukum \\
& tertentu. Pembahasan penelitian penulis mengemukakan bahwa; \\
& adanya peningkatan ekonomi nasional di Indonesia pada tahun \\
& 2020 hingga 2021 akibat dampak dari perjanjian kerjasama \\
& dagang Indonesia dan Australia. Demikian, dapat disimpulkan \\
& bahwa perjanjian internasional yang dilakukan oleh Indonesia \\
dan Australia memberikan keuntungan bagi hubungan & diplomatik kedua negara serta mengakibatkan kemajuan \\
& ekonomi akibat dari hukum yang berlaku serta mengikat kedua \\
& negara tersebut.
\end{tabular}

\section{ABSTRACT}

Indonesia Australia Economic Partnership is a partnership agreement or what is called a bilateral agreement between the two countries. This economic agreement will regulate the Indonesian market for Australian exporters. More than 99\% of Australian goods exports to Indonesia by value will be 


\begin{tabular}{ll}
\hline & calculated duty free. In this agreement, the authors found an \\
& increase in the Indonesian economy when participating in the \\
& International I-A CEPA Agreement. The increase occurred due \\
& to the minimization of the risk of loss for both countries in the \\
& economic field. The method used in this research is a normative \\
& legal research method, which is a legal research library. The \\
& data used are secondary data derived from books and articles on \\
& trade agreements between Indonesia and Australia. In addition, \\
& the approach used is a conceptual approach and a statutory \\
& approach. The theoretical framework used as the basis for the \\
& analysis is the theory of international treaties according to \\
& Mochtar Kusumaatmadja which explains that international \\
& agreements are agreements made between nations aimed at \\
& binding certain laws. Discussion of the author's research \\
& suggests that; an increase in the national economy in Indonesia \\
in 2020 to 2021 due to the impact of the trade cooperation \\
agreement \\
agreement between Indonesia and Australia. Thus, it can be \\
analysis; \\
international; \\
Indonesia-Fiji \\
cooperation
\end{tabular}

\section{Pendahuluan}

Perjanjian internasional merupakan suatu wujud implementasi kerjasama antara suatu negara dengan negara mitranya. Di samping itu, perjanjian internasional juga menggambarkan pentingnya suatu posisi negara tersebut dalam peraturan diplomasi di tingkat bilateral. Sejak kemerdekaan Republik Indonesia tahun 1945, Indonesia telah menandatangani 6619 perjanjian dan mengimplementasikan berbagai perjanjian dengan negara dan entitas asing. Berbagai perjanjian tersebut disimpan di rumah yang disebut Treaty Room yang dikelola oleh Kementerian Luar Negeri (Roisah, 2015).

Kini di abad ke-21, kami di Kementerian Luar Negeri terus berupaya meningkatkan akses publik atas berbagai perjanjian di Treaty Room. Melalui pemutakhiran laman web Treaty Room. Perjanjian bilateral diharapkan dapat memberikan dampak yang mendukung kepentingan nasional negara. Perjanjian yang disebut dengan Indonesia- Australia Comprehensive Economic Partnership atau (I-A CEPA). Perjanjian Kemitraan Ekonomi Komprehensif Indonesia-Australia (IA-CEPA) menciptakan kerangka kerja untuk era baru hubungan ekonomi yang lebih erat antara Australia dan Indonesia dan membuka pasar dan peluang baru untuk bisnis, produsen utama, penyedia jasa, dan investor. IA-CEPA adalah perjanjian komprehensif, dibangun berdasarkan perjanjian-perjanjian multilateral dan regional yang telah ada termasuk Perjanjian Pembentukan Kawasan Perdagangan Bebas ASEAN - Australia - Selandia Baru (AANZFTA). IA-CEPA mulai berlaku pada 5 Juli 2020. Adapun hasil dan tujuan dari perjanjian IA CEPA (Ambaranie Nadia Kemala Movanita, 2018). 
a. Dibangun berdasarkan AANZFTA, IA-CEPA akan memberikan akses yang lebih baik dan lebih pasti ke pasar Indonesia untuk eksportir Australia. Lebih dari 99\% ekspor barang Australia ke Indonesia berdasarkan nilai akan bebas bea masuk atau di bawah pengaturan preferensi yang meningkat secara signifikan. Australia akan segera mengeliminasi semua tarif impor dari Indonesia ke Australia yang tersisa.

b. IA-CEPA mengandung seperangkat aturan modern berkualitas tinggi yang mengatur perlakuan terhadap jasa dan investasi, serta aturan modern tentang perdagangan digital.

c. Sebagai bagian dari paket keterampilan secara keseluruhan, Australia dan Indonesia telah sepakat untuk Pertukaran Keterampilan timbal balik, yang memungkinkan para profesional dari kedua negara untuk mendapatkan pengalaman selama 6 bulan di pasar pihak lain.

d. IA-CEPA mencakup kerangka kerja untuk perdagangan dan yang terkait investasi melalui program kerja yang didanai bersama. Program kerja bersama ini akan mendukung kegiatan bantuan teknis dan peningkatan kapasitas di berbagai bidang terkait perdagangan untuk memperkuat hubungan komersial dan membantu menstimulir investasi dua arah (Retno L.P. Marsudi, 2009).

Sebelum IA-CEPA resmi diberlakukan, Indonesia telah menyusun teknis pelaksanaan agar ke depannya implementasi IA-CEPA dapat berjalan lancar serta meminimalisir hambatan. Hal ini diungkapkan oleh Iman Pambagyo selaku Dirjen Perundingan Perdagangan Internasional yang turut menyusun peraturan untuk penurunan tarif dan penerbitan surat keterangan asal (SKA). Sosialisasi mengenai IACEPA juga tengah dilakukan kepada seluruh jajaran Kantor Kepabeanan dan Instansi Penerbit Surat Keterangan Asal dan pemerintah daerah. Perjanjian ini memuat peniadaan tarif bea cukai, IA-CEPA dapat menjadi katalis peningkatan ekspor produk Indonesia ke pasar Australia, seperti produk otomotif, tekstil, kayu, karet, elektronik, mesin, makanan dan minuman, serta pengembangan industri kreatif. Di luar perdagangan, Australia juga menyiapkan 200 visa magang di berbagai sektor prioritas, mulai dari pendidikan hingga teknologi informasi.

IA-CEPA menjadi jembatan antara Indonesia dan Australia, di mana kedua negara ini dapat saling memanfaatkan keunggulan satu sama lain untuk meningkatkan produktivitas serta meminimalisir biaya operasional. Sebagai contoh di sektor makanan dan minuman, Indonesia dapat menggunakan bahan pangan yang diimpor dari Australia dengan harga yang lebih terjangkau dan produk olahan tersebut dapat dijual kembali dengan harga bersaing di Australia.

Momentum Bersejarah Bagi Hubungan Indonesia dan Australia, IA-CEPA Resmi Berlaku Hari Ini Jakarta, 5 Juli 2020 merupakan hari yang bersejarah bagi hubungan bilateral Indonesia dan Australia karena Perjanjian Kemitraan Ekonomi Komprehensif antara Indonesia dan Australia (Indonesia-Australia Comprehensive Economic Partnership Agreement/IA- CEPA) resmi berlaku. Kerja keras kedua Pemerintah dalam proses perundingan dan ratifikasi kini terbayarkan, dan para pelaku usaha dan 
pemangku kepentingan Indonesia sekarang mulai dapat memanfaatkan IA-CEPA. Berlakunya IA-CEPA didukung dengan diterbitkannya tiga peraturan pelaksana yaitu:

1. Peraturan Menteri Perdagangan Nomor 63 Tahun 2020 tentang Ketentuan Asal Barang Indonesia dan Ketentuan Penerbitan Dokumen Keterangan Asal untuk Barang Asal Indonesia dalam Kemitraan Ekonomi Komprehensif antara Indonesia dan Australia;

2. Peraturan Menteri Keuangan No. 81/PMK.10/2020 tentang Penetapan Tarif Bea Masuk dalam rangka Persetujuan Kemitraan Ekonomi Komprehensif IndonesiaAustralia;

3. Peraturan Menteri Keuangan No. 82/PMK.04/2020 tentang Tata Cara Pengenaan Tarif Bea Masuk atas Barang Impor Berdasarkan Persetujuan Kemitraan Ekonomi Komprehensif Indonesia-Australia.

IA-CEPA akan memberikan manfaat bagi eksportir Indonesia melalui penghapusan seluruh tarif bea masuk Australia sehingga seluruh produk Indonesia yang masuk ke pasar Australia akan menikmati tarif 0 persen. Produk ekspor Indonesia yang berpotensi meningkat ekspornya antara lain adalah otomotif, kayu dan turunannya termasuk kayu dan furnitur, perikanan, tekstil dan produk tekstil, sepatu, alat komunikasi dan peralatan elektronik. Oleh karena itu penulis akan menguraikan rumusan masalah yaitu (Rantung, 2020);

1. Bagaimana dampak implementasi Indonesia - Australian Comprehensive Economic Partnership Agreement terhadap peningkatan ekonomi nasional?

\section{Metode Penelitian}

Penelitian hukum normatif pada dasarnya mengkaji hukum yang dikonsepkan sebagai norma atau kaidah yang berlaku dalam masyarakat (Valerine, 2015). Penelitian ilmu hukum Menurut Peter, M, Marzuki dilakukan untuk mencari pemecahan atas isu hukum yang timbul sehingga hasil yang dicapai menerima hipotesis, melainkan memberikan presepsi mengenai apa yang seyogyanya atas itu yang dilanjutkan. Peter Mahmud Marzuki menggolongkan beberapa pendekatan dalam penelitian normatif yang terdiri dari;

a. Pendekatan Undang-undang (statute approach)

b. Pendekatan kasus (case approach)

c. Pendekatan historis (historical approach)

d. Pendekatan perbandingan (comparative approach)

e. Pendekatan konseptual (conceptual approach)

Dalam penelitian hukum ini, sumber bahan hukum terdiri dari tiga sumber tersebut terdiri dari:

a. bahan hukum primer terdiri dari perundang-undangan

b. bahan hukum sekunder yaitu mencankup semua bahan hukum yang dipublikasi.

c. bahan hukum tersier merupakan bahan-bahan yang memberikan penjelasan 
Untuk mendukung bahan hukum sekunder misalnya, kamus-kamus. Penelitian hukum ini juga terdiri dari beberapa langkah untuk menelusuri bahan hukum. Bahan hukum sekunder yang digunakan sebagai penelitian hukum kepustakaan dan penelitian hukum teoritis/dogmatis. Penelitian ini dilakukan dengan tiga metode data sekunder dalam menelusuri bahan hukum yaitu:

1. Studi pustaka; Bahan pustaka yang juga disebut sebagai data sekunder terutama dapat diperoleh dari perpustakaan. Banyak orang menganggap perpustakaan hanyalah sebagai suatu tempat terkumpulnya buku-buku atau gudang buku. Pendapat demikian tidaklah benar. Perpustakaan merupakan gudang ilmu pengetahuan serta tempat terhimpunnya ilmu pengetahuan yang diperoleh manusia dari masa ke masa.

2. Dokumen, dan Studi arsip yang berkaitan dengan isu hukum dari permasalahan dalam penelitian. Jika, berkaitan dengan hukum agrarian dan hak guna usaha maka data yang diambil berupa data sekunder dengan bahan hukum dekumen dan studi arsip. Adapun data sekunder Menurut Abdul Kadir Muhammad; data sekunder antara lain bahan hukum yaitu yang berasal dari hukum yakni perundang-undangan, dokumen hukum, putusan pengadilan, laporan hukum dan catatan hukum yang berasal dari pengetahuan hukum yaitu ajaran atau doktrin hukum, teori hukum, pendapat hukum, ulasan hukum. Data atau bahan yang diperoleh, yang berupa hasil dari pengelolahan data sekunder melalui analisis data kualitatif, yakni; analisis data dengan cara menguraikan data secara bermutu dalam bentuk kalimat yang teratur, runtun, logis, tidak tumpang tindih, dan efektif, sehingga memudahkan interpretasi data dan pemahaman hasil analisis. Pengertian analisis kualitatif adalah menganalisis data yang berasal dari bahan hukum konsep, teori, peraturan-peraturan perundangundangan, dokrin, prinsip hukum, pendapat atau pandangan penelitian sendiri. Penelitian ini, penulis melakukan analisis deskriptif dalam melakukan analisis. Maka penulis berfokus pada dua pendekatan yaitu: Pertama, Pendekatan perundangundangan (Statute Approach);

1) Indonesia-Australia Comprehensive Economic Partnership Agreement/IA- CEPA

2) Peraturan Menteri Perdagangan Nomor 63 Tahun 2020 tentang Ketentuan Asal Barang Indonesia dan Ketentuan Penerbitan Dokumen Keterangan Asal untuk Barang Asal Indonesia dalam Kemitraan Ekonomi Komprehensif antara Indonesia dan Australia (Australia \& Indonesia, 2020);

3) Peraturan Menteri Keuangan No. 81/PMK.10/2020 tentang Penetapan Tarif Bea Masuk dalam rangka Persetujuan Kemitraan Ekonomi Komprehensif IndonesiaAustralia;

4) Peraturan Menteri Keuangan No. 82/PMK.04/2020 tentang Tata Cara Pengenaan Tarif Bea Masuk atas Barang Impor Berdasarkan Persetujuan Kemitraan Ekonomi Komprehensif Indonesia-Australia.

Kedua, Pendekatan Konsep; merupakan suatu pendekatan yang dilakukan untuk mengetahui perjajian ekonomi internasional kedua negara. Dalam pendekatan ini penulis menemukan bahwa; adanya dampak perjanjian internasional I-A CEPA terhadap peningkatan ekonomi nasional, hal ini merupakan akibat dari hukum itu 
sendiri, yang memberikan dampak bagi kemajuan serta kesejateraan umum. Berdasarkan Undang-Undang Dasar Negara Kesatuan Republik Indonesia.

\section{Hasil dan Pembahasan}

\section{A. Perjanjian Indonesia-Australia Comprehensive Economic Partnership Agreement Atau IA- CEPA}

Australia merupakan negara maju yang menjadi salah satu mitra dagang penting bagi Indonesia. Jumlah penduduk lebih dari 23 juta jiwa, dengan pertumbuhan ekonomi ril rata-rata 2,75\% per tahun selama 5 tahun terakhir. Dari segi geografis, letak Australia yang terpisah dari negara lainnya menjadikan Indonesia sebagai mitra yang potensial bagi Australia. IA-CEPA dibentuk dengan konsep "Economic Powerhouse" yaitu kolaborasi antara Indonesia- Australia dengan memanfaatkan keunggulan negara masing-masing untuk menyasar pasar di kawasan atau di negara ketiga, contohnya pada industri makanan olahan berbahan dasar daging, yang didatangkan dari Australia dan diolah di Indonesia untuk tujuan Timur Tengah. Demikian juga gandum seperti mi instan yang dengan bahan baku gandum Australia akan mendapatkan ongkos produksi yang lebih rendah sehingga dapat bersaing di pasar global. Konsep ini juga dapat diterapkan pada industri lainnya seperti industri software, perfilman, efek dan animasi, dan lainnya. Konsep Economic Powerhouse juga didukung dengan pembukaan akses dan perlindungan investasi yang lebih baik dalam IA-CEPA, sehingga mendorong masuknya investor Australia ke Indonesia terutama di sektor-sektor yang diminati Australia seperti pendidikan tinggi, pendidikan vokasi, kesehatan, industri, konstruksi, energi, pertambangan, dan pariwisata (Tehupeiory, 2016). Di sisi lain, dengan adanya IA-CEPA, investor Indonesia juga akan lebih terlindungi dalam melakukan ekspansi usaha dengan melakukan penanaman modal di Australia. Sedangkan dari segi people to people dan pembangunan sumber daya manusia, Indonesia juga akan mendapatkan program kerja sama ekonomi seperti pendidikan vokasional dan program magang yang disusun berdasarkan kebutuhan sektor Industri Indonesia, juga tersedianya visa magang di sembilan profesi di sektor prioritas yaitu pendidikan, pariwisata, telekomunikasi, pengembangan infrastruktur, kesehatan, energi, pertambangan, jasa keuangan, teknologi informasi dan komunikasi dan peningkatan kuota work and holiday visa (Iit Septyaningsih, 2020).

Salah satu pendekatan konkret saat ini adalah rencana dibukanya Universitas Australia di Indonesia, yang dipercaya akan berdampak positif bagi dunia pendidikan tinggi di Indonesia. Mendag Agus mengajak seluruh pelaku usaha Indonesia, pemerintah daerah, akademisi, investor bersama-sama memanfaatkan perjanjian ini semaksimal mungkin, agar memberi manfaat bagi ekonomi Indonesia. "Covid-19 membuat hampir seluruh negara di dunia mengalami perlambatan pertumbuhan ekonomi, sehingga IA CEPA dapat dijadikan momentum dan dorongan untuk menjaga kinerja perdagangan dan meningkatkan daya saing Indonesia. Untuk memperoleh informasi lebih dalam atas IA-CEPA dan cara untuk memanfaatkannya, 
pelaku usaha dapat berkonsultasi langsung dengan Free Trade Agreement (FTA) Center yang dikoordinasi Kementerian Perdagangan yang terdapat di lima kota besar yaitu Jakarta, Bandung, Surabaya, Makassar, dan Medan.

Sekilas Perdagangan Barang/Jasa dan Investasi Kedua Negara dan Perundingan IA-CEPA Total perdagangan barang Indonesia-Australia pada 2019 mencapai USD 7,8 miliar. Ekspor Indonesia tercatat senilai USD 2,3 miliar dan impor sebesar USD 5,5 miliar, sehingga Indonesia mengalami defisit sebesar USD 3,2 miliar. Namun demikian, dari sepuluh besar komoditas impor Indonesia dari Australia mayoritas merupakan bahan baku dan penolong industri, seperti gandum, batubara, bijih besi, alumunium, seng, gula mentah, serta susu dan krim. Sementara dari sisi perdagangan jasa menurut statistik Australia, pada periode 2018 - 2019 ekspor jasa Indonesia mencapai AUD 4,4 miliar dan impor jasa sebesar AUD 1,7 miliar yang menjadikan Indonesia suplus AUD 2,7 miliar. Sektor penyumbang surplus Indonesia adalah sektor jasa pariwisata dan transportasi, sementara Indonesia mengimpor jasa terkait pendidikan dari Australia. Adapun investasi Australia di Indonesia pada 2019 mencapai USD 264 juta dengan 740 proyek di sektor pertambangan, industri logam, tanaman pangan, hotel dan restoran, listrik, gas dan air, industri makanan, industri kimia dan farmasi serta perdagangan dan reparasi.

Perundingan IA-CEPA diluncurkan pada 2 November 2010 oleh Presiden RI dan Perdana Menteri Australia. Perundingan pertama dan kedua diselenggarakan pada September 2012 dan Juli 2013, tetapi terhenti selama 3 tahun. Pada Maret 2016, Indonesia dan Autralia sepakat melanjutkan kembali perundingan dan setelah melalui 12 putaran perundingan dan 5 pertemuan tingkat Ketua Perunding, kedua negara berhasil menyelesaikan perundingan secara substansial pada 31 Agustus 2018. IACEPA kemudian ditanda tangani oleh Menteri Perdagangan RI dan Menteri Perdagangan, Pariwisata dan Investasi Australia di Jakarta, pada 4 Maret 2019. IACEPA telah disahkan.

Perjanjian IA-CEPA diharapkan semakin mempermudah aktivitas investasi, baik bagi investor asal Indonesia yang ingin melakukan ekspansi maupun investor Australia yang tertarik untuk menanamkan modal di perusahaan Indonesia. Selama ini, Indonesia menduduki peringkat 12 sebagai negara tujuan investasi Australia. Terbentuknya IA-CEPA diharapkan mampu menjadi dorongan bagi Indonesia untuk melesat masuk ke top 10 negara tujuan investasi Australia (Verimasri, 2020). IACEPA menjadi perlindungan dan fasilitas investasi bagi investor di kedua negara ini terutama di sektor infrastruktur, energi, pariwisata, pengolahan makanan, pendidikan tinggi, dan pengembangan teknologi. Pemberlakuan IA-CEPA pada bulan Juli ini menjadi angin segar bagi tingkat investasi di Indonesia yang mengalami penurunan dikarenakan pandemi COVID-19.

Perjanjian internasional sudah selayaknya terjadi di antara negara-negara atau masyarakat internasional untuk mengembangkan negara atau memenuhi kebutuhan masing-masing dalam maksud bekerjasama dalam mencari keuntungan. Hubungan ini diatur dalam Konvensi Wina 1969 yang memberikan pengertian perjanjian 
internasional adalah perjanjian yang diadakan oleh dua negara atau lebih bertujuan untuk mengadakan akibat-akibat hukum tertentu. Menurut OppenheimerLeuterpacht; perjanjian internasional adalah suatu persetujuan antarnegara yang menimbulkan hak dan kewajiban di antara pihak-pihak yang mengadakannya. Sedangkan menurut G. Schwarzenberger; perjanjian internasional adalah persetujuan antara subyek-subyek hukum internasional yang menimbulkan kewajiban-kewajiban yang mengikat dalam hukum internasional, dapat berbentuk bilateral ataupun multilateral. Menurut Mochtar Kusumaatmadja; perjanjian internasional adalah perjanjian yang diadakan antarbangsa yang bertujuan untuk menciptakan akibat dari hukum-hukum tertentu. Kemudian menurut hukum positif di Indonesia sendiri, dalam pasal 1 angka 1 Undang-Undang nomor 24 Tahun 2000 tentang Perjanjian Internasional, perjanjian internasional adalah perjanjian, dalam bentuk dan nama tertentu, yang diatur dalam hukum internasional yang dibuat secara tertulis serta menimbulkan hak dan kewajiban di bidang hukum publik. Seperti yang dilakukan oleh Indonesia dan Australia merupakan subyek hukum internasional yang melakukan perjanjian internasional jenis perjanjian atau agreement/persetujuan (Asikin, 2016). Prakteknya pembuatan perjanjian internasional persetujuan umumnya mengatur materi yang memiliki cakupan lebih kecil dibanding materi yang diatur pada traktat atau dengan kata lain substansi atau materi yang diatur dalam agreement bersifat khusus mencakup para pihak saja disebut dengan IndonesiaAustralia Comprehensive Economic Partnership Agreement.

\section{B. Dampak Indonesia-Australia Comprehensive Economic Partnership Agreement Terhadap Ekonomi Nasional}

Perjanjian Internasional jenis ini memuat sebuah konsep yaitu; 'Economic Powerhouse' adalah merupakan kolaborasi kekuatan ekonomi untuk mendorong produktifitas produk industri dan pertanian, dan meningkatkan ekspor ke pasar negara ketiga. Kedua negara dapat berkontribusi lebih besar pada 'global value chains' untuk memasok kebutuhan global. Indonesia diproyeksikan menjadi manufacturing powerhouse (pusat pengolahan), dengan kemudahan akses berbagai bahan baku dan penolong murah serta berkualitas dari Australia, sebagai contoh impor ternak bahan baku bagi industri pengolahan daging. Contoh bentuk kerja sama yang sudah diinisiasi: Grain Partnership Industri Besi dan Baja. Australia menyediakan bahan baku gandum, sorghum dan barley, dan kerja sama pengembangan industry makanan olahan Indonesia. Menangkap peluang ekspor kebutuhan konstruksi seiring pesatnya pembangunan global. Akses Pasar Barang; Australia mengeliminasi semua pos tarifnya (6474 pos tarif) menjadi $0 \%$ pada saat implementasi (Australian Government, 2020).

Beberapa produk Indonesia yang berpotensi ditingkatkan ekspornya ke Australia: Produk Otomotif (mobil, sepeda motor, dll) Preferensi/kemudahan ekspor mobil hybrid dan listrik berupa ketentuan asal barang berupa: change in tariff heading (CTH) or qualifying value content (QVC) $35 \%$ or built in Indonesia from a Complete Knock Down kit for Electric \& Hybrid Car. Tekstil dan Produk Tekstil 
(Pakaian, T-Shirt, Celana, Jersey) Preferensi tarif bea masuk 0\% dari yang sebelumnya 5\%, sehingga dapat berkompetisi kembali dengan Malaysia, Thailand dan Vietnam yang sebelumnya sudah mendapatkan pembebasan tariff. Produk Lainnya Peralatan elektronik, permesinan, karet dan turunannya (ban), kayu dan turunannya (furniture), kopi, coklat, dan kertas. Produk-produk ini sudah; mendapatkan preferensi tarif bea masuk 0\% dari Australia, namun dapat lebih ditingkatkan ekspornya melalui Konsep 'Economic Powerhouse'.

Salah satu bidang yang akan terdampak dengan adanya perjanjian ini adalah bidang peternakan. Kerja sama ini dinilai bisa memberi kepastian bagi sektor usaha di bidang peternakan, seperti ekspor 570 ribu sapi Australia ke Indonesia dengan fasilitas bebas bea masuk. Sebelum Kemitraan IA-CEPA diberlakukan, Indonesia mengenakan tarif sebesar 5\% untuk importasi sapi hidup dari Australia. Pembebasan tarif akan diberlakukan secara bertahap dalam beberapa tahun. Selain dari sisi tarif, kuota impor sapi bakalan akan meningkat secara bertahap hingga mencapai 700 ribu ekor pada 2026 (Konsulat Jenderal Republik Indonesia, 2019).

Berdasarkan data BPS pada tahun 2020, secara umum dan hampir menyeluruh di 6 pulau besar di Indonesia, kebutuhan akan daging sapi lebih tinggi dibandingkan dengan ketersediaan akan daging sapi itu sendiri. Defisit tertinggi terjadi di pulau Jawa dengan produksi hanya sebesar 254,58 ribu ton, jauh lebih sedikit dibandingkan dengan permintaan akan daging sapi yang mencapai 517,43 ribu ton sehingga terjadi defisit sebesar 262,85 ribu ton. Dengan adanya perjanjian ini diharapkan dapat berdampak positif terhadap jumlah supply daging sapi di pasaran (Enggartiasto Lukita, 2018).

IA CEPA akan menciptakan peluang investasi baru dan iklim investasi yang lebih kondusif. Hal ini penting untuk meningkatkan jumlah FDI Australia di Indonesia, dan sebaliknya. Pada tahun 2017, jumlah FDI Australia di Indonesia mencapai USD 513 juta, dengan sektor unggulan adalah pertambangan, tanaman pangan dan perkebunan, industri logam dasar dan barang logam, dan hotel serta restoran. Melalui IA CEPA, Investor Australia diharapkan akan mendapatkan kemudahan untuk berinvestasi di sektor jasa keuangan, agribisnis, pariwisata, pertambangan, rumah sakit, infrastruktur dan pendidikan. Namun demikian, untuk sektor-sektor strategis, Indonesia tetap memiliki kontrol atas jumlah investasi asing yang masuk ke negara Indonesia. Peningkatan kegiatan ekspor dari IndonesiaAustralia dapat diwujudkan dengan implementasi Indonesia-Australia Comprehensive Economic Partnership Agreement (IA-CEPA) atau Persetujuan Kemitraan Ekonomi Komprehensif Indonesia-Australia yang dituangkan dalam IACEPA (kementerian investasi/bkpm, 2020). Permendag no. 63 Tahun 2020 menjadi acuan penerapan ketentuan penerbitan Surat Keterangan Asal (SKA) atau Deklarasi Asal Barang (DAB) untuk ekspor tujuan Australia. Ekspor ke Australia, eksportir dapat memilih mengunakan skema AANZ-FTA atau skema IA-CEPA. Jika eksportir memilih menggunakan skema IA-CEPA maka bukti asal barang dapat berupa Surat Keterangan Asal (SKA) atau Deklarasi Asal Barang (DAB). DAB memiliki kekuatan 
hukum dan fungsi yang sama dengan SKA sehingga DAB tidak dapat digunakan secara bersamaan dengan SKA terhadap barang yang sama dalam satu shipment. Cukup pilih salah satu saja untuk mendapatkan preferensi di Australia.

1) Deklarasi Asal Barang (DAB)

Deklarasi Asal Barang (DAB) adalah pernyataan asal barang yang dibuat oleh Eksportir Terigistasi (ER) untuk ekspor barang sesuai ketentuan perundangan-undangan yang berlaku untuk mendapatkan tarif preferensi. Untuk menggunakan DAB, eksportir harus terdaftar sebagai eksportir Terigistrasi (ER) melalui sistem e-SKA. DAB hanya dapat dibuat oleh Eksportir yang telah terigistrasi dan diberi kewenangan oleh Kementerian Perdagangan untuk mengeluarkan DAB (Origin Declaration) untuk barang ekspor asal Indoensia.

2) Barang Originating

Australia memberikan 0\% import duty bagi seluruh produk asal Indonesia. Untuk dapat menikmati manfaat $0 \%$ (nol persen) dari IA-CEPA tersebut, barang yang diekspor harus originating berdasarkan HS Code yang terkait dalam perjanjian IA-CEPA (Siaran Pers, 2020). Barang dikatakan originating diantaranya jika memenuhi ketentuan sebagai berikut: Barang yang secara keseluruhan diperoleh atau diproduksi dalam wilayah suatu negara, contohnya tumbuhan seperti produk produk holtikultura, binatang hidup seperti ikan dan hasil budidaya air dan lainnya. Kode yang digunakan adalah WO (Wholly Obtained). Barang yang tidak seluruhnya diperoleh atau diproduksi di dalam wilayah suatu negara, contohnya Tekstil Produk Tekstil, aneka kerajinan dan lain lain. Kode yang dicantumkan pada SKA adalah RVC. Barang yang diproduksi dalam wilayah suatu negara secara eksklusif dari bahan originating.

3) Surat Keterangan Asal

Beberapa catatan penting lainnya tentang prosedur Surat Keterangan Asal (SKA) IA-CEPA : SKA yang menggunakan Third Party Invoice yang diterbitkan di negara selain negara anggota harus memenuhi ketentuan: Pencantuman nama perusahaan yang menerbitkan Third Party Invoicing pada kolom 9 SKA; Pemberian tanda centang (v) pada kolom 12 SKA pada kotak Third Party Invoicing; Jika SKA Hilang atau rusak maka harus tertulis Certified True Copy, dan SKA yang baru hanya bisa diterbitkan kurang dari 12 bulan sejak tanggal penerbitan SKA yang hilang Masa berlaku SKA IA-CEPA adalah 12 bulan sejak tanggal penerbitan. Jika diterbitkan lebih dari 3 hari setelah tanggal pengapalan maka Issued Retroactively. Ketentuan mengenai IA-CEPA selengkapnya dapat dipahami melalui : Permendag No 63 Tahun 2020 Tentang Ketentuan Asal Barang Indonesia (Rules Of Origin Of Indonesia) dan Ketentuan Penerbitan Dokumen Keterangan Asal untuk Barang Asal Indonesia dalam Indonesia-Australia Comprehensive Economic Partnership Agreement (Persetujuan Kemitraan Ekonomi Komprehensif Indonesia-Australia).

Sejalan dengan visi Presiden Joko Widodo untuk meningkatkan sumber daya manusia melalui mengembangkan pendidikan vokasi (vocational education 
and training-VET) serta sektor pendidikan tinggi, Indonesia berkomitmen untuk membuka lebih banyak akses investasi Australia di sektor pendidikan. Indonesia berharap Australia dapat berinvestasi lebih banyak di sektor VET dan pendidikan tinggi. IA-CEPA juga mengatur kerja sama kedua negara dalam bidang pertukaran tenaga terampil dan professional di beberapa bidang seperti di industri keuangan, asuransi, pertambangan dan teknologi informasi dan komunikasi.

Karena sifat perdagangan Indonesia dan Australia yang komplementer, industri nasional juga mendapat manfaat berupa ketersediaan sumber bahan baku dengan harga lebih kompetitif karena tarif bea masuk nol persen. Industri hotel restoran dan katering, serta industri makanan dan minuman akan mendapatkan harga bahan baku yang lebih berdaya saing sehingga konsumen dapat menikmati lebih banyak varian serta harga lebih terjangkau.

\section{Kesimpulan}

Perjanjian Indonesia-Australia Comprehensive Economic Partnership merupakan salah satu perjanjian internasional yang disebut dengan perjanjian bilateral. Perjanjian ini memuat beberapa peraturan dalam bidang ekspor-import yang mengikat kedua negara yaitu; Indonesia dan Australia. Perjanjian ini mengatur beberapa hal antara lain; Australia mengeliminasi semua pos tarifnya (6474 pos tarif) menjadi $0 \%$ pada saat implementasi dan sebaliknya. Kedua negara sepakat dalam hukum internasional yang disebut dengan perjanjian I-A CEPA. Seperti yang dijelaskan oleh Mocthar Kusumaatmadja bahwa; hukum internasional memiliki dampak bagi negara yang menjadi subjek hukum. Hal ini sesuai dengan kehadiran I-A CEPA yang memberikan dapat bagi ekonomi nasional Indonesia. Dampaknya adanya perjanjian ini diharapkan dapat berdampak positif terhadap jumlah supply daging sapi di pasaran dan semakin banyak investor asal Australia yag berdatangan ke Indonesia, hal ini selaras dengan visi Presiden Jokowi dalam Undang-Undang Nomor 11 Tahun 2020 tentang Cipta Kerja dalam bidang investasi. 
Heni Novalisa Tabisu, Aartje Tehupeiory, Diana R. W Napitupulu

\section{BIBLIOGRAFI}

Ambaranie Nadia Kemala Movanita. (2018). Indonesia-Australia Sepakati CEPA, Ini Poin Pentingnya. Kompas.Com. https://ekonomi.kompas.com/read/2018/09/07/121 439826/indonesia-australia-sepakati-cepa-ini-poin-pentingnya. Google Scholar

Asikin, Z. (2016). Hukum Dagang. Google Scholar

Australia, K. B., \& Indonesia. (2020). Perdagangan dan Investasi. Indonesia.Embassy.Gov.Au. https://indonesia.embassy.gov.au/jaktindonesian/trade .html. Google Scholar

Australian Government. (2020). Indonesia-Australia Comprehensive Economic Partnership Agreement (IA-CEPA). Austrade.Gov.Au. https://www.austrade.gov.au/australian/export/free-trade-agreements/iacepa. Google Scholar

Enggartiasto Lukita. (2018). Indonesia-Australia Comprehensive Economic Partnership Agreement (Ia-Cepa). Ditjenppi.Kemendag.Go.Id. https://ditjenppi.kemendag.go.id/assets/files/publikasi/doc_20181015_fact-sheetindonesia-australia-cepa.pdf. Google Scholar

Iit Septyaningsih. (2020). Perjanjian Dagang IA-CEPA Telah Resmi Berlaku. Republika.Co.Id. https://republika.co.id/berita/qd198x383/perjanjian-dagangiacepa-telah-resmi-berlaku. Google Scholar

Kementerian Investasi/bkpm. (2020). IA-CEPA Pacu Kerja Sama Ekonomi Indonesia dan Australia. Investindonesia.Go.Id. https://www.investindonesia.go.id/id/artikelinvestasi/detail/ia-cepa-pacu-kerja-sama-ekonomi-indonesia-dan-australia. Google Scholar

Konsulat Jenderal Republik Indonesia. (2019). Ratifikasi Indonesia-Australia Comprehensive Economic Partnership Agreement (IA-CEPA) Akan Dorong Kerja Sama Ekonomi Antara Indonesia dan Australia. Kemlu.Go.Id.

https://kemlu.go.id/melbourne/id/news/4701/ratifikasi-indonesia-australiacomprehensive-economic-partnership-agreement-ia-cepa-akan-dorong-kerja-samaekonomi-antara-indonesia-dan-australia. Google Scholar

Rantung, F. (2020). Apa Saja Manfaat Dari Perjanjian Dagang IA-CEPA, Ini

Rinciannya. Ekbis.Sindonews.Com. https://ekbis.sindonews.com/read/97140/34/ap a-saja-manfaat-dari-perjanjian-dagang-ia-cepa-ini-rinciannya-1594390027. Google Scholar

Retno L.P. Marsudi. (2009). Ministry of Foreign Affairs of The Republic of Indonesia. Kemlu.Go.Id. https://treaty.kemlu.go.id/aboutus/info/about_treaty_room. Google Scholar 
Roisah, K. (2015). Hukum Perjanjian Internasional: Teori dan Praktek. Setara Press. Google Scholar

Siaran Pers. (2020). Momentum Bersejarah Bagi Hubungan Indonesia Dan Australia, IA-CEPA Resmi Berlaku Hari Ini. Kemendag.Go.Id.

https://www.kemendag.go.id/storage/article_uploads/rFcf8TZUlOwBDZuWKbajx sn4M1X7iEsvTOLpNMR7.pdf. Google Scholar

Tehupeiory, A. (2016). Pengakuan Hukum Nasional Terhadap Hukum Adat Dalam Kepemilikan Dan Pengolahan Tanah. Jurnal Tora, 2 (3), 393-400. Google Scholar

Valerine, J. L. K. (2015). Metode Penelitian Hukum (Bagian I). Jakarta: Program Pasca Sarjana Fakultas Hukum Universitas Indonesia. Google Scholar

Verimasri. (2020). Indonesia-Australia Comprehensive Economic Partnership Agreement (IA-CEPA). Eksporindonesia.Com.

https://eksporindonesia.com/indonesia-australia-comprehensive-economic-

partnership-agreement-ia-cepa/. Google Scholar

\section{Copyright holder:}

Heni Novalisa Tabisu, Aartje Tehupeiory, Diana R. W Napitupulu (2021)

First publication right:

Jurnal Syntax Admiration

This article is licensed under:

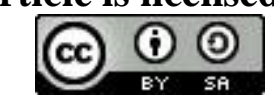

